\title{
Study on the Financial Leverage Effect Based On the Financing Activities of SMEs
}

\author{
Shuo Feng \\ School of Economoic Management, North China Electric Power University, Baoding, 071000, China \\ fengshuozhenguan@qq.com
}

\begin{abstract}
With the rapid development of Chinese market economy, SMEs are becoming more active in the modern national economy. However, SMEs have difficulty in financing because of their small size and low market share. In recent years, the economic policies to support SME financing, but with the status of the international poor economic recovery, SMEs have been struggled to survive. In this paper, the use of financial leverage and financing of SMEs, adjust the debt ratio rationally, better use of financial leverage effect, to optimize the allocation of capital structure, so as to promote enterprise financing activities.
\end{abstract}

Keywords: Financial leverage effect; SEMs; financing activities.

\section{Introduction}

In recent years, the international economic recovery is weak, the financial environment is worsening, and the difficulty of financing is increasing. Liability as one of the main ways of enterprise financing, it can be described as a double-edged sword. Use it to bring leverage effect, enterprise can get rich benefits. On the contrary, the enterprise may drop into the abyss, or even bankruptcy. Therefore, the rational use of financial leverage, optimization of the capital structure, and promotion of the healthy growth of enterprises is the core of enterprise financial management.

Financial leverage due to fixed costs, when a small amount of financial variables change, the other relevant quantity will be greatly changed, the role of financial leverage is to pay the fixed cost of capital financing to increase the Shareholder equity. The size of the financial leverage is generally measured by the degree of financial leverage (DFL), the rate of change in profits after tax is equivalent to a multiple of the rate of change in Earnings before Interest and Tax (EBIT). The greater the degree of financial leverage, the greater the return of financial leverage, while the greater the risk of financial leverage, and vice versa.

Study the impact of financial leverage on corporate financing, the key to pay attention to the proportion of debt financing, which usually involves part of the theory of capital structure. Many theories in history have made different analysis and judgment on the capital structure of enterprises, which was put forward by the famous economist Modigliani and MM in 1958. The subsequent development of Agency Cost Theory, Pecking Order Theory, Signaling Theory from different angles has enriched the theory of capital structure.Based on that, Numerous empirical studies for corporate financing clarifies in modern commercial society, debt management is an effective strategic tool: Modigliani and Miller's MM Correction Theory is that borrowing can brings to the enterprise tax preferences; Jensen and Meckling put forward the leverage to reduce the agency costs of the company. Ross believes that debt management helps to enhance the creditors of the company's future earnings confidence, the value of the company's interests have a positive signal; Timan and Wessels $(1988,1998)$ strong profitability of companies generally higher debt ratio and profitability of weak enterprise more rely on equity investment. Obviously, the financial leverage decision has very important function in the enterprise financing decision. The management and control of the debt management should be one of the strategic objectives of the enterprise. 


\section{The Impact of Financial Leverage on Corporate Financing Capital Structure}

When the enterprises' capital structure is fixed, and long-term debt management quota unchanged, the smaller the financial leverage degree is, the benefit of the enterprise more favorable; financial leverage degree is big that EBIT of corporate is low, debt management will reduce enterprise to bring the benefits. The size of EBIT rate compared with debt interest rate is divided into two kinds of situation analysis:

Assuming EBIT is greater than the debt interest rate, also is the financial leverage can bring the positive effect to enterprise, enterprises should increase the amount of debt. More debt to the enterprise's Equity Fund Rate of Return is more favorable, at this time will need a larger financial leverage degree.

Assuming that the enterprise's interest rate is less than the interest rate of debt, financial leverage will bring negative effects, which requires a smaller financial leverage degree, should not continue to operate. But from the perspective of long-term development of enterprises, even in the case of a short loss, but also to consider the operation of debt.

\section{Econometric Analysis of Financial Leverage}

Table 1 The Main Way of Financing for SMEs

\begin{tabular}{|c|c|c|c|c|}
\hline $\begin{array}{c}\text { Enterprise } \\
\text { ExistenceTime(Years) }\end{array}$ & Self-financing(\%) & Bank Loans(\%) & $\begin{array}{c}\text { Non-financial } \\
\text { institutions(\%) }\end{array}$ & Other channels(\%) \\
\hline$\leqq 3$ & 92.4 & 2.7 & 2.2 & 2.7 \\
\hline $3-5$ & 92.1 & 3.5 & 0.0 & 4.4 \\
\hline $6-10$ & 89.0 & 6.3 & 1.5 & 3.2 \\
\hline$\geqq 10$ & 83.1 & 5.7 & 9.9 & 1.3 \\
\hline Total & 90.5 & 4.0 & 2.6 & 2.9 \\
\hline
\end{tabular}

From the table can be drawn, SMEs enterprise financing is mainly concentrated in the self-financing. On the current global economic situation, it is becoming increasingly difficult to raise capital by self-financing. Therefore, it is necessary to consider a reasonable capital structure, which requires the financial leverage effect.

First of all, the financial leverage degree is one of the indicators to measure the financial leverage, which is the ratio between the rate of change in the rate of earnings per share and the rate of change of EBIT. If the financial leverage degree is slightly greater than 1, the rate of change of earnings per share is smaller, the company's debt interest is smaller, and the financial leverage effect is not obvious, so that the company's potential financial risk is small.

Secondly, the financial leverage is the use of debt financing to raise the additional revenue to the business owners.

Under the operating conditions of liabilities:

$\hat{\mathrm{E}}=[\mathrm{E}+\mathrm{D} *(\mathrm{E}-\check{\mathrm{D}})]^{*}(1-\mathrm{I})$

Under the operating conditions of no liabilities:

$F=[E-\check{D})] * D$

$\hat{E}$-Equity expected return rate E-Expected rate of return on total assets $\check{D}$-Debt expected return rate I-Income tax rate F-Financial leverage return rate D-Debt-equity ratio

If the rate of return on investment is far greater than the debt-equity ratio, debt financing to bring the financial leverage to the enterprise, there is a positive effect of financial leverage. If reducing the proportion of debt in the capital structure, the ratio of property rights is reduced, which make better use of the financial leverage, and achieve the financial leverage.

\section{Summary}

Compared with other financing methods, the financing cost is relatively small. In a certain period of time, the reasonable and effective increase in the proportion of liabilities can reduce the cost of capital. Therefore, the debt financing brought by the financial leverage can bring better benefits for 
enterprises to achieve the purpose of optimizing the capital structure of enterprises. Through the case analysis to see, debt financing will not only bring benefits to the enterprise, will also bring a certain degree of financial risk to the enterprise, that is to say, the debt ratio is larger, the greater financial risk faced by the enterprises. Therefore, the enterprise should be based on the economic environment and the actual situation of their own development, reasonable adjustment of debt ratio, and better use of financial leverage, to achieve the purpose of optimizing the allocation of capital structure.

\section{References}

[1] Zhao Rong1. Analysis on the relationship between the growth of small and medium sized enterprises and the financial leverage. Finance and Accounting Research. (2014) No. 17, p. 116.

[2] Guo Lihong1.Research on the relationship between the financing gap and the financial leverage of the small and medium sized enterprises in China. Chinese Academic Journal Electric Pubilishing House. Beijing, 2009.

[3] Mclchionno Rick1.The Changing Temporary Work Force. Managerial Professional and Technical Works in the Personnel Supply Services Industry Occupailonal Outlook Qquartcrly, 43(1), 1999.

[4] Mark A.Rothstein1, Charles B. Craver, Elinor P.Schroeder2, Elaine W.Shoben3, Employment Law [M].West, 2005.

[5] William Smith1.The Serve Two Masters, MR Magazine, (33), 1988.

[6] Leah F.Vosk1.Leased Workers and the Law.Legitimizing the Triangular Employment Relationship.Emerging International Labor Standards from a Comparative Perspactive. Comparative 1.abor I.aw \& Policy JoumaI, 21(3), 1997. 